"Fuzzy reporting as a way for a company to greenwash: perspectives from the Colombian reality"

\begin{tabular}{|c|c|}
\hline AUTHORS & $\begin{array}{l}\text { Orlando E. Contreras-Pacheco (D https://orcid.org/0000-0002-3584-7063 } \\
\text { Cyrlene Claasen }\end{array}$ \\
\hline ARTICLE INFO & $\begin{array}{l}\text { Orlando E. Contreras-Pacheco and Cyrlene Claasen (2017). Fuzzy reporting as } \\
\text { a way for a company to greenwash: perspectives from the Colombian reality. } \\
\text { Problems and Perspectives in Management, 15(2-3), 525-535. } \\
\text { doi:10.21511/ppm.15(si).2017.06 }\end{array}$ \\
\hline DOI & http://dx.doi.org/10.21511/ppm.15(si).2017.06 \\
\hline RELEASED ON & Wednesday, 27 September 2017 \\
\hline RECEIVED ON & Tuesday, 18 April 2017 \\
\hline \multirow[t]{2}{*}{ ACCEPTED ON } & Wednesday, 10 May 2017 \\
\hline & (cc) EY-NC \\
\hline LICENSE & $\begin{array}{l}\text { This work is licensed under a Creative Commons Attribution-NonCommercial } 4.0 \\
\text { International License }\end{array}$ \\
\hline JOURNAL & "Problems and Perspectives in Management" \\
\hline ISSN PRINT & $1727-7051$ \\
\hline ISSN ONLINE & $1810-5467$ \\
\hline PUBLISHER & LLC “Consulting Publishing Company "Business Perspectives" \\
\hline FOUNDER & LLC "Consulting Publishing Company "Business Perspectives" \\
\hline & $\begin{array}{l}\text { =- } \\
= \pm=\end{array}$ \\
\hline NUMBER OF REFERENCES & NUMBER OF FIGURES \\
\hline 54 & 2 \\
\hline
\end{tabular}

(C) The author(s) 2023. This publication is an open access article. 


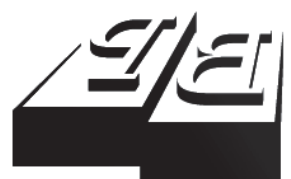

BUSINESS PERSPECTIVES

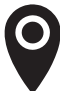

LLC "CPC "Business Perspectives" Hryhorii Skovoroda lane, 10, Sumy, 40022, Ukraine

www.businessperspectives.org

Received on: $18^{\text {th }}$ of April, 2017 Accepted on: $10^{\text {th }}$ of May, 2017

C Orlando E. Contreras-Pacheco, Cyrlene Claasen, 2017

Orlando E. Contreras-Pacheco, Associate Professor, Universidad Industrial de Santander, School of Industrial Engineering and Business, Colombia.

Cyrlene Claasen, Assistant Professor, Rennes School of Business, Rennes, France.

\section{FUZZY REPORTING AS A WAY FOR A COMPANY TO GREENWASH: PERSPECTIVES FROM THE COLOMBIAN REALITY}

\begin{abstract}
Drawing on the legitimacy theory framework, this study introduces an alternative means to spot "fuzzy reporting" signals as a way to detect greenwashing at the firm level. Its approach is based on the way the sustainability reporting process can mislead stakeholders after critical incidents take place. In order to do so, a single environmental incident, which took place in Colombia, is analyzed in light of what happened before, during and afterwards, with special emphasis on the corporate disclosure process performed by the company involved. Results obtained give support to the assumption that fuzzy reporting can be objectively detected not only through the analysis of annual sustainability reports, but also by tracking other forms of corporate messages when a specific concern is carefully followed. This study's contribution is two-fold. First, it builds on the theoretical notions of greenwashing and fuzzy reporting by illustrating a practical and objective way to identify some deceiving corporate practices. Second it empirically evaluates this approach in a sensitive context in order to obtain better illustration and prepare the groundwork for further studies.
\end{abstract}

\section{Keywords}

legitimacy, corporate social responsibility (CSR), greenwashing, sustainability reports, social and environmental reporting, fuzzy reporting, mining industry, Colombia

\section{JEL Classification M49, Q01, Q33, Q56}

\section{INTRODUCTION}

Understanding that every company has the right (and duty) to defend its legitimacy under critical circumstances is a key notion in the general management body of knowledge. This is probably one of the reasons why the analysis of instruments like sustainability reports (SRs) is subject to an increasing trend of research in different academic fields. Among other purposes, SRs should ideally work as a means to communicate with real and specific details those contingencies, crises, and incidents faced by the companies involved during a specific period of time. Some of those companies, however, are not able to (or simply not interested in) disclose the truth behind specific episodes, so they end up camouflaging the reality through different ways and ultimately deceive their stakeholders (Berrone, 2016). One way to effectively do that is by manipulating the information included in their SRs thanks to the use of fuzzy language and subtle contradictions (Crilly, Hansen, \& Zollo, 2016). However, this phenomenon is not totally apparent to the naked eye. This study intends to address this phenomenon that recognizes it as a condemnable act of deception. In particular, it points out the way that greenwashing is performed through the manipulation of official SRs. 
Supported by the use of content analysis followed by exhaustive media tracking, we put forward an approach that identifies evident signals of fuzzy reporting (FR) by relying on more than just annual SRs. We based this study on recent contributions to the topic (Berrone, 2016; Crilly et al., 2016), which developed useful avenues to contribute to the academic debate. Furthermore, we use a single case study as a pilot to better illustrate our proposal. In this sense, we could gather strong evidence to make the assumption that FR is detected not only through the analysis of annual SRs, but also by tracking and comparing other forms of corporate messages (e.g., press releases, media statements, and official declarations). We suggest this is possible, especially when a specific variable is predefined and rigorously tracked after environmental/social incidents have to be faced by companies. In order to do that, we use as a focal point a specific environmental disaster that occurred in 2013, which involved a North American-based company belonging to the Colombian coal mining industry.

The contribution of this paper is two-fold. First, we make a reinforcement of the theoretical notion of greenwashing by illustrating a practical way to identify some deceiving corporate practices (in the way of FR). Second, we illustrate an effective empirical analysis of this approach by referring to a particular case study in a sensitive and complex context. The purpose of this application is centered on providing illustration and preparing the groundwork for further studies.

\section{GREENWASHING AND ORGANIZATIONAL LEGITIMACY}

Walker and Wan (2012) define greenwashing as the gap between "symbolic" and "substantive" corporate social actions (CSA). Symbolic CSA includes what the company claims to do in terms of socially responsible behaviors, and substantive CSA is what the company is actually doing or has done in terms of CSA. Somehow, the presence of that gap represents an organizational way of " $\operatorname{cog}$ nitive dissonance" (Festinger, 1962) in the field of CSR, which exists in both organizational and product decisions. The focus of the present work is on the firm level of greenwashing.

In this sense, an important perspective that will be analyzed is the role of corporate communications when a scenario of CSR deception takes place. Delmas and Burbano (2011) helped to understand in a graphic way a logical definition of environmental greenwashing in relation to the messages that a certain company conveys to its stakeholders (see Figure 1). Companies that have a negative CSR performance and at the same time apply a positive communication about their CSR performance are, naturally, in the spotlight of this work.

A known alternative to approach the notion of greenwashing in the literature is when it is linked with the wider concept of legitimacy. In their work, Dowling and Pfeffer (1975) suggest that legitimacy is based on the coherence among the values claimed by a certain organization, its practices, and the norms of adequate behavior in the society. Thus, according to this definition, greenwashing implies the absence of legitimacy (Milne \& Patten, 2002) and the organizational need to do something (even mislead) in order to obtain it. Conversely, greenwashing can be seen also as a legitimation strategy used when organizations voluntarily promote an impression of legitimate social and environmental values even when they do not have stronger social and environmental records (Mahoney et al., 2013).

The topic of greenwashing emerged in recent years and has increasingly drawn attention, especially in the way it acquires different shapes into different levels. Its study is particularly interesting for industries involved in natural resources-related business because of their implications and costs to the environment and society (Bowen \& Aragon-Correa, 2014). At the same time, any attempt to address the study of greenwashing in the context of developing countries is always worthwhile due to their "special" (i.e. weak) regulatory policies (Delmas \& Burbano, 2011). That is why the Colombian coal mining industry is a promising arena to analyze the concept in order to identify its occurrence, understand its nature, and provide some useful "takeaways" with both theoretical and practical implications. 


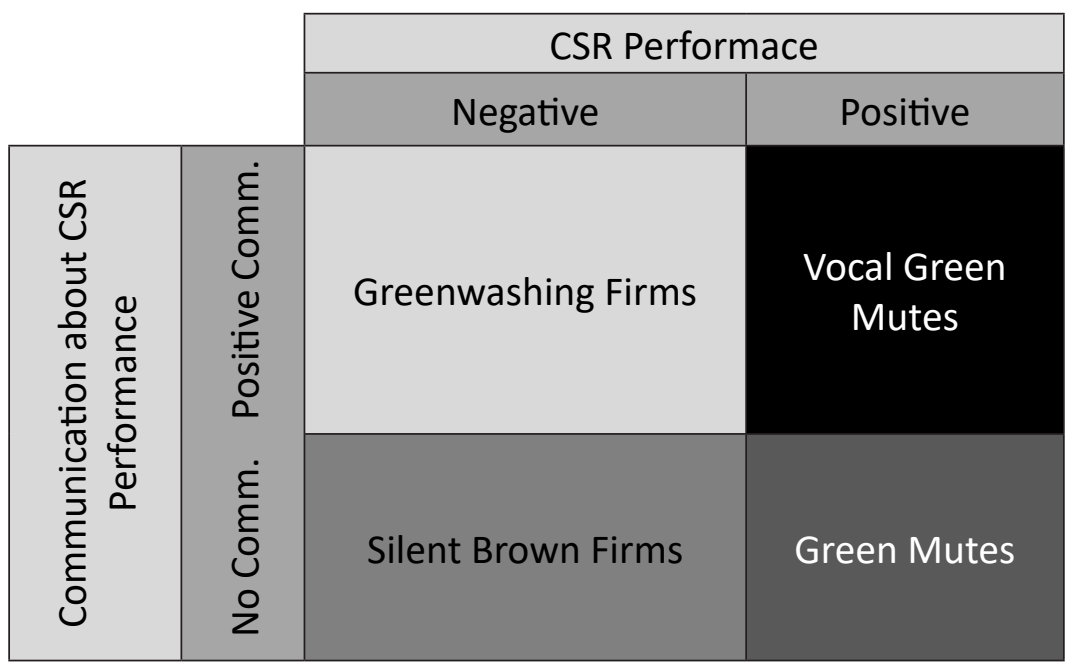

Figure 1. A typology of firms based on CSR performance and communication

\subsection{Greenwashing transgressions}

In his book, Berrone (2016) appeals to the original approach to greenwashing, which is, according to him, the most cited criterion for understanding a set of four firm-level transgressions (Bruno, 1992). Furthermore, Berrone also contributed to this categorization by adding a fifth transgression, which is related to the way companies formally account for their CSR actions. The five ways a company can transgress greenwashing were originally named (i) dirty business; (ii) ad bluster; (iii) political spin; (iv) It is the law, stupid!; and (v) FR (see Figure 2).

As mentioned before, the focal point of this work is FR, since it represents a current contribution and a potential topic to build on through research.

\begin{tabular}{|l|l|} 
Dirty Business & $\begin{array}{l}\text { Belonging to an inherently unsustainable business, but promoting sustainable } \\
\text { practices or products that are not representative neither for the business } \\
\text { nor the society. }\end{array}$ \\
Political Spin & $\begin{array}{l}\text { Diverting attention from sustainable issues through the use of advertising. It is } \\
\text { used to exaggerate achievements or present alternative programs that are not } \\
\text { related with the main sustainability concern. }\end{array}$ \\
It's the Law, & $\begin{array}{l}\text { Influencing regulators or governments in order to obtain benefits that affect } \\
\text { sustainability. It is common to notice that these spins are "justified" due to the } \\
\text { companies' character of large tax payers or employers. }\end{array}$ \\
Proclaiming sustainability accomplishments or commitments that are already \\
required by existing laws or regulations.
\end{tabular}

Figure 2. Greenwashing transgressions by companies 


\subsection{Fuzzy reporting (FR)}

In their efforts to gain legitimacy, some companies have chosen to account for their sustainability performance through frequent SRs (Guthrie \& Parker, 1989). Those reports are supposed to represent a way of communication to the main companies' stakeholders in order to get them involved in a common agenda of collective welfare (Berrone, Fosfuri, \& Gelabert, 2015). In other words, SRs should allow "organizations to measure, understand and communicate their economic, environmental, social and governance performance, and then set goals, and manage change more effectively" (Katamba \& Nkiko, 2017, p. 346).

Gray, Owen, and Adams (1996) defined sustainability reporting (also called social and environmental reporting, or simply SER) as "the process of communicating the social and environmental effects of organizations' economic actions to particular stakeholders, and to society in general" (p. 3). Thus, it should be understood that SRs are genuinely meant to act as tools of organizational transparency. However, SER is actually interpreted as a method of self-presentation and impression management conducted by companies to ensure various stakeholders are satisfied with their public behaviors (see Bansal \& Clelland, 2004). In fact, SRs are also catalogued as routines mostly implemented with economic purposes (Dienes, Sassen, \& Fisher, 2016), and that actually works pretty well for this sake (Bachmann \& Ingenhoff, 2016). However, given the nature and sensitivity of the issues and the infinite possibilities to interpret measures, understand facts, and communicate messages, reporting has become a source of study due to its capacity to be manipulated through language (Yekini, Burrows, \& Omoteso, 2014).

It has been said that, instead an objective accountability of facts, SER has been rather applied by some companies as a 'managerial construction of reality' (Campbell, 2000). In this same vein, scholars like Cho and Patten (2007), Deegan (2014) and O'Donovan (2002) effectively suggest that SRs are instruments aimed to repair the legitimacy of organizations. Sometimes, organizations can even produce a legitimizing effect by restricting its own sustainability information disclosures (De Villiers \& van Staden, 2006). Likewise, the work of
Spence (2009) concludes that somehow, these SRs can in fact be vehicles whereby some companies can communicate with themselves instead of with their stakeholders. As a result, there is a real debate about to what extent SER could be considered a confident mechanism for discharging social and environmental accountability (Marquis \& Toffel, 2011). Consequently, it is logic to think that any intention to make them confused (or better fuzzy) has to be considered as a way for a company to systematically greenwash. Incidentally, some of the most interesting examples of this questioned (but popular) practice are found in developing countries (Katamba \& Nkiko, 2017), and particularly in the natural resources production sector (Bowen \& Aragon-Correa, 2014).

Conventional approaches in the literature have been focused on the study of conventional annual SRs rather than other channels of communication (e.g., Alonso-Almeyda et al., 2015; Morhardt et al., 2002). Berrone (2016) himself explicitly refers to the annual discipline of reporting when posits FR phenomenon as the 5th greenwashing transgression. Nevertheless, it is also valid to consider other scholars' works, which have identified alternative forms of reporting as accepted instruments of communication with stakeholders. Particularly, the study conducted by Frost, Jones, Loftus and Van der Laan (2005), following Adams and Frost's (2006) approach, enhances the concept of annual SER and suggests that other communication practices such as corporate websites, press items, environmental booklets and internal magazines, among others, can be considered also SRs. In this way, the phenomenon of FR could be performed in any kind of social and environmental disclosure divulged with the intention of manipulating the truth.

One thing is true: the public is focusing now more than ever on what firms are saying about sustainability (Snider et al., 2003). However, at the same time, people believe that companies' SRs use fails to accurately reflect sustainability behavior, that is, that they do not always "walk their talk". Nevertheless, some "specialist" stakeholders (like NGOs) are able to identify instances of greenwashing in those reports (Berrone et al., 2015); it is also suggested that "conventional" stakeholders are not prepared to effectively interpret them. Some 
works have helped to tackle this issue from the linguistic and discursive perspective (e.g., Crilly et al., 2016; Yekini et al., 2014). The claim of the present work is that a new avenue can be developed through a deep analysis of critical incidents and the manner in which "greenwashers" report them.

\section{METHODOLOGY}

By following Yin (1994) and Eisenhardt (1989), we support this research with the use of a case study to illustrate a theoretical approach in the field of FR as a greenwashing transgression. In this sense, the Colombian coal mining industry was defined as the general subject, and the disclosures of the company studied were the particular subjects of study. To do that, we relied on a two-stage qualitative methodology of a content analysis and coding, followed by a rigorous on-line search of messages conveyed about a particular critical incident. The event chosen is henceforth called the TS-115 incident, which happened between January 12 and 13, 2013, in the Colombian Northern coast. The company involved is Drummond Ltd.

\subsection{Data collection}

The TS-115 incident was registered and understood from different perspectives and versions, such as from the company, regulator (ANLA), and media. It was subsequently subject to a rigorous scrutiny of every ex-post message conveyed by the company involved about its surrounding circumstances. Those messages, which for the sake of this study we consider SRs, were collected from several and accredited on-line public sources oriented to different audiences (i.e., company's stakeholders). In this sense, annual SRs, press releases, internal communications, professional presentations, governmental proceedings and media items (most of them translated from Spanish into English) generated up to 3 years after the incident were extensively analyzed. A total of 109 SRs were examined, classified and reduced to 19 workable SRs in which one particular variable was explicitly mentioned and assessed by the company. Those figures were, in turn, compared among them and with the one obtained by scientific means (around 2,000 tons; Invemar, 2013), in order to obtain signals that could confirm a deception, and therefore a company's FR behavior.

\subsubsection{Colombia and Drummond}

Coal mining accounted for more than $12 \%$ of Colombia's GDP in 2015 (Simco.gov.co, n.d.). Furthermore, this country is the fifth biggest producer of this mineral worldwide and the most important exporter in America (Plazas, 2016), with a total production of more than 85.5 million tons in 2015 (Simco.gov.co, n.d.). Therefore, the Colombian coal mining industry is a large taxpayer, as well as a highly labor-intensive industry, which accounts for more than 20,000 employees, both directly and indirectly (Valencia, 2014). Consequently, it is officially defined as one of the "railway engines" of the country's current path of development (Garay et al., 2013). On the other hand, this industry is regulated by the National Authority of Environmental Licenses (hereinafter ANLA), which represents the highest Colombia's environmental agency, meaning that miners are compelled to be accountable with it for their actions and omissions.

On the other hand, Drummond's activities in that country, which began in 1987, represent the most important operation of Drummond Company Inc., one of the 210 largest private North American corporation (Forbes.com, 2017). Currently, Drummond is one of the biggest exporters of Colombia's thermal coal, and has control over around 2 billion tons of coal reserves. This mineral is extracted from open-pit mines and transported to its own deep-water ocean port (Puerto Drummond) located in the Caribbean Sea from which, until 2014, it had been exported through a barge-based system. Drummond is one of the most important suppliers of thermal coal to coal-power plants in the U.S., Europe, and Israel (Simco.gov.co, n.d.).

Despite its well-elaborated CSR rhetoric and rigorous policies (Drummondltd.com, n.d.), the company has also been highly questioned for suspicious non-sancta practices that have been notorious in recent years (Garay et al., 2013; Huertas et al., 2012; Jiménez, 2014; Otálora, 2015; Shaefer, 2014). Consequently, it is suggested that Drummond could be using CSR and its reporting process as a "defensive strategy" to deal better with their accusations of CSR transgressions and human rights violations (Sarmiento, 2008). 


\subsubsection{The TS-115 incident}

At 1:00 a.m. on Sunday, January 13, 2013, as part of a normal operation in Puerto Drummond, one of the company's barges, initially loaded with almost 3,000 tons of coal, was temporally towed and left moored to a buoy due to bad weather conditions. The storms and high waves continued, and water began to enter the moored vessel, causing instability. Several hours later, after Drummond's personnel noticed the critical situation of the semi-submerged barge, the emergency alarm was activated and cranes were deployed to indiscriminately scoop out the coal in order to recover the barge's buoyancy (Drummond Ltd., 2015). By the end of this operation, around 1,870 tons of coal were dumped into the sea from these actions (ANLA, 2013, 2014). An environmental disaster had just occurred just off Colombia's shores, and the public deserved to be informed of it. Strangely, this is not what happened at all.

Although Drummond alleged to have reported the incident to the corresponding harbor jurisdiction, they decided not to disclose the incident to anyone else directly after its occurrence (not even to the ANLA). Surprisingly, 17 days later, the company was caught "red-handed" by an independent journalist who published some impressive images of the environmental disaster (Molinski, 2013). This fact outraged the Colombian public opinion, and Drummond felt the pressure of having to face the entire society in order to justify their actions and decisions. From that moment, and during an ANLA's official investigation (which was obviously activated afterwards), Drummond went from one falsehood to another: descriptions that did not match, partial and selective disclosing of information, cherry-picking of data that apparently played in their defense, and a later non-compliance with the government's order to suspend operations in the port immediately (ANLA, 2014).

\subsection{Data analysis}

Despite its apparent simplicity of estimation (i.e., initial load - remainder), one of the issues that dis-

Table 1. Potential variables to analyze

Source: own.

\begin{tabular}{|c|c|c|c|c|c|c|}
\hline & Variable \# & Type & $\begin{array}{c}\text { Version } \\
\text { pro-company }\end{array}$ & $\begin{array}{l}\text { Version } \\
\text { against company }\end{array}$ & $\begin{array}{l}\text { Possible } \\
\text { scenarios }\end{array}$ & $\begin{array}{c}\text { Nature } \\
\text { of the issue }\end{array}$ \\
\hline 1 & Concealment & $\begin{array}{l}\text { Dichotomic / } \\
\text { Argumentative }\end{array}$ & $\begin{array}{l}\text { According to the } \\
\text { company's past } \\
\text { experiences, they } \\
\text { had to report the } \\
\text { incident to the } \\
\text { Santa Marta Harbor } \\
\text { Master; which they } \\
\text { did it that day }\end{array}$ & $\begin{array}{l}\text { The regulator } \\
\text { claimed that } \\
\text { according to } \\
\text { Colombian laws, } \\
\text { every incident has } \\
\text { to be reported to } \\
\text { the environmental } \\
\text { authority }\end{array}$ & $\begin{array}{l}\text { The company is } \\
\text { either right or wrong } \\
\text { in not reporting to } \\
\text { the environmental } \\
\text { authority }\end{array}$ & Legal \\
\hline 2 & Overloading & Dichotomic & $\begin{array}{l}\text { The capacity of } \\
\text { TS- } 115 \text { was never } \\
\text { excessed }\end{array}$ & $\begin{array}{l}\text { With negative } \\
\text { antecedents in } \\
\text { weather conditions, } \\
\text { the amount loaded } \\
\text { on TS-115 should be } \\
\text { lower }\end{array}$ & $\begin{array}{l}\text { Either there was } \\
\text { excess or not in } \\
\text { the amount of coal } \\
\text { loaded in TS-115 }\end{array}$ & $\begin{array}{l}\text { Technical / human } \\
\text { (decision) }\end{array}$ \\
\hline 3 & Contamination & Ordinal scale & $\begin{array}{l}\text { According to expost } \\
\text { scientific studies, } \\
\text { the incident didn't } \\
\text { represent negative } \\
\text { environmental effects }\end{array}$ & $\begin{array}{l}\text { Coal mineral is a } \\
\text { pollutant to the } \\
\text { environment, as } \\
\text { it is described in } \\
\text { Drummond's internal } \\
\text { documents }\end{array}$ & $\begin{array}{l}\text { Different levels } \\
\text { of possible } \\
\text { environmental } \\
\text { impact }\end{array}$ & Scientific \\
\hline 4 & Negligence & Dichotomic & $\begin{array}{l}\text { Bad weather and } \\
\text { darkness made } \\
\text { impossible to notice } \\
\text { the condition of the } \\
\text { TS-115 up the sunset }\end{array}$ & $\begin{array}{l}\text { A protocol of } \\
\text { surveilance was not } \\
\text { applied, especially in } \\
\text { particular conditions } \\
\text { (weather and TS-115 } \\
\text { situation) }\end{array}$ & $\begin{array}{l}\text { Either there was } \\
\text { negligence or not } \\
\text { from Drummond's } \\
\text { employees }\end{array}$ & Human \\
\hline 5 & Impromptu & $\begin{array}{l}\text { Dichotomic / } \\
\text { argumentative }\end{array}$ & $\begin{array}{l}\text { Contingency plan } \\
\text { was implemented }\end{array}$ & $\begin{array}{l}\text { Contingency plan } \\
\text { was not implemented }\end{array}$ & $\begin{array}{l}\text { Either there was } \\
\text { application or not of } \\
\text { contingency plan }\end{array}$ & Operative \\
\hline 6 & Quantity & $\begin{array}{l}\text { Numerical } \\
\text { scale }\end{array}$ & $\begin{array}{l}9 \text { different versions } \\
\text { (from } 35 \text { to } 500 \text { tons) }\end{array}$ & $\begin{array}{l}\text { According to } \\
\text { scientific studies, } \\
1,870 \text { tons of mineral } \\
\text { coal were dumped to } \\
\text { ocean }\end{array}$ & $\begin{array}{l}\text { Different amounts of } \\
\text { coal dumped }\end{array}$ & $\begin{array}{l}\text { Unknown (could be } \\
\text { operative, human, or } \\
\text { technical) }\end{array}$ \\
\hline
\end{tabular}


turbed the most about the TS-115 incident, was the company's incapacity to declare a precise amount of coal dumped into the seabed during that day (Semana.com, 2013). Therefore, we concentrate on finding out the variable of "quantity," over other potential factors of study (like the concealment of facts and the potential contamination (see Table 1). The reason for this determination rests on the variable's nature of the data. In this sense, the mention of a particular amount was entirely objective, verifiable, and traceable compared to other issues. After all, the company performed several declarations, statements, interviews, and testimonies about this particular concern. Consequently, every single mention of that specific variable was carefully picked and compared. The findings obtained are presented in the next section.

\section{RESULTS}

A total of nine different references were selected and chronologically analyzed. Two press releases (PR1 and PR2), one interview (In), two official testimonies (OT1 and OT2), one statement to the media (DM), one conference with representatives of the mining industry (Co), one internal magazine (IM), and the 2013-2014 (SRD) were the public sources from which relevant information was gathered. From these, the company declared the same number of different versions of "quantity", and none of them was coincident with the reality $(1,870$ tons). As can be seen in Table 2 , every mention of the amount represented one out of three possibilities: explicit approximation, deduction of the corresponding text, or acceptance of unawareness. Two special cases were the official statements provided to ANLA when the research took place: the first instance (OT1) and the appealing process (OT2), when the company altered its previous testimony. The company stated these two mentions as definitive figures in two different instances.

It is evident how the company changed its versions according to the situation and to the stakeholders addressed. For instance, after 107 tons, which was deduced in PR1, it declared an estimate of 300 tons (In) and expressed uncertainty four days later

Table 2. Mentions of the amount of coal dumped into the ocean

Source: own.

\begin{tabular}{|c|c|c|c|c|c|c|}
\hline Ref. & Type & Date & Source & Title and information & $\begin{array}{c}\text { Stakeholder } \\
\text { adressed }\end{array}$ & "Quantity" \\
\hline PR1 & $\begin{array}{l}\text { Press } \\
\text { release \# } 1\end{array}$ & 14-Feb-13 & $\begin{array}{l}\text { Drummond's web } \\
\text { page }\end{array}$ & $\begin{array}{l}\text { Statement by Drummond Ltd. - barge's } \\
\text { accident internal investigation results } \\
\text { (Drummondltd.com, 2013) }\end{array}$ & Media & 107 tons \\
\hline In & Interview & 17-Feb-13 & $\begin{array}{l}\text { El Tiempo } \\
\text { (Colombian } \\
\text { newspaper) }\end{array}$ & $\begin{array}{l}\text { According to Drummond, "300 tons } \\
\text { of coal were dumped into the sea" } \\
\text { - Interview to Josu Miguel Linares, } \\
\text { Drummond's Interim CEO (Eltiempo. } \\
\text { com, 2013) }\end{array}$ & General public & 300 tons \\
\hline DM & $\begin{array}{l}\text { Declaration } \\
\text { to the media }\end{array}$ & 21-Feb-13 & $\begin{array}{l}\text { El Paнs (Colombian } \\
\text { newspaper) }\end{array}$ & $\begin{array}{l}\text { "We don't know how much coal were } \\
\text { dumped into the ocean" - Testimony, } \\
\text { of Josh̆ Miguel Linares, Drummond's } \\
\text { interim CEO (Elpais.com.co, 2013) }\end{array}$ & General public & Undetermined \\
\hline Co & Conference & 21-Feb-13 & $\begin{array}{l}\text { Drummond's } \\
\text { web page - 2nd. } \\
\text { Conference of the } \\
\text { High Scale Mining } \\
\text { Industry (SMGE) }\end{array}$ & $\begin{array}{l}\text { Rescue Operation of the barge TS-115 - } \\
\text { PPT presented by Drummond's interim } \\
\text { CEO (Drummond Ltd., 2013; Layton, } \\
\text { 2013) }\end{array}$ & $\begin{array}{l}\text { Mining } \\
\text { industry } \\
\text { executives } \\
\text { and official } \\
\text { representatives }\end{array}$ & 150 tons \\
\hline OT1 & $\begin{array}{l}\text { Official } \\
\text { testimony } \\
\text { to ANLA } 1\end{array}$ & 3-Apr-13 & ANLA's web page & $\begin{array}{l}\text { Testimony of Drummond's legal } \\
\text { representative, during ANLA's } \\
\text { investigation (ANLA, 2013) }\end{array}$ & $\begin{array}{l}\text { Environmental } \\
\text { authority } \\
\text { (government) }\end{array}$ & 35 tons \\
\hline IM & $\begin{array}{l}\text { Institutional } \\
\text { magazine }\end{array}$ & Dec-13 & $\begin{array}{l}\text { Drummond's web } \\
\text { page - Revista } \\
\text { Drummond } 2013\end{array}$ & $\begin{array}{l}\text { Findings after the barge's incident } \\
\text { (Drummond Ltd., 2013) }\end{array}$ & Employees & $\begin{array}{l}\text { Undetermined } \\
\text { (but "a little } \\
\text { ammount of } \\
\text { coal") }\end{array}$ \\
\hline PR2 & $\begin{array}{l}\text { Press } \\
\text { release \# } 2\end{array}$ & 19-Jan-14 & $\begin{array}{l}\text { Drummond's web } \\
\text { page }\end{array}$ & $\begin{array}{l}\text { Drummond Ltd. responds with FACTS } \\
\text { and asks WHY? (Drummondltd.com, } \\
\text { 2014) }\end{array}$ & Media & 200 tons \\
\hline OT2 & $\begin{array}{l}\text { Official } \\
\text { Testimony } \\
\text { to ANLA } 2\end{array}$ & 21-Jan-14 & ANLA's web page & $\begin{array}{l}\text { Drummond's administrative appeal } \\
(\text { ANLA, 2014) }\end{array}$ & $\begin{array}{l}\text { Environmental } \\
\text { authority } \\
\text { (government) }\end{array}$ & 180,66 tons \\
\hline SRD & $\begin{array}{l}\text { Sustainability } \\
\text { report }\end{array}$ & 27-Oct-15 & $\begin{array}{l}\text { Drummond's web } \\
\text { page }\end{array}$ & $\begin{array}{l}\text { Drummond's sustainability report 2013- } \\
2014 \text { (Drummond Ltd., 2015) }\end{array}$ & $\begin{array}{l}\text { Shareholders, } \\
\text { community, } \\
\text { NGOs }\end{array}$ & $300-500$ tons \\
\hline
\end{tabular}


(DM). Besides, its legal representative declared under oath that the amount dumped was only 35 tons (OT1) three months later. Moreover, it is important to mention that the company apparently did not accept the ANLA indictment of having dumped around 1,870 tons of coal. Instead, for its last testimony, Drummond ex- ecutives submitted a "royalties payment invoice" for 180,66 tons (OT2) as proof, according to them, of this quantity. However, in a surprising turn, they finally mentioned in the SRD (more than two years later) a range between 300 and 500 tons as the actual amount of coal dumped during TS-115 incident.

\section{DISCUSSION AND CONCLUSION}

The purpose of this work was to put forward an alternative way to understand and detect evidence of FR at the firm level. In order to do it, we concentrated in every form of social and environmental communication at the firm level. Our findings indicated support for organizational legitimacy theory as an explanatory factor for Drummond's misleading messages (Cho and Patten, 2007; Deegan, 2014; O'Donovan, 2002). Furthermore, they are consistent with previous studies in the sense that SER is ultimately considered an effective driver for systematic disclosure of positive information without full disclosure of negative information (Bansal \& Clelland, 2004; Guthrie \& Parker, 1989).

In order to understand this alternative way and following our approach, we suggest to: 1) focus on a single social or environmental incident; 2) define a specific variable to focus on; and 3) analyze and track official mentions of that same variable through several public sources (SRs). When analyzing Drummond's TS-115 incident, we observed that, besides being far from the truth, different mentions of the pre-determined variable ("quantity") were different among each other, as well as from what was officially reported by the company in its annual SR (SRD; which strangely for this unique instance turned to be actually a bi-annual SR).

This work is in accordance with other studies which have found that companies belonging to mining and energy industries tend to "camouflage sustainability" through their SRs (Bowen \& Aragon-Correa, 2014). Apparently, these companies take advantage of asymmetric information (meaning that constituencies possess different information than the company) to manipulate the truth and "persuade" their audiences. However, from many perspectives, stakeholders are becoming more aware of this organizational behavior, which could lead to a reduction of organizational credibility (Katamba \& Nkiko, 2017). Particularly, what we suggest in the present work revolves around an important risk of proliferation of FR practices as a way of greenwashing in developing countries, which can bring self-defeating consequences for their development. The latter statement builds upon some previous contextual contributions in the Colombian mining industry these last years (Garay et al., 2013; Jiménez, 2014; Otálora, 2015; \& Sarmiento, 2008).

In terms of practical implications, this paper addressed the idea that although different stakeholders like shareholders, the community, the media, and the government have different expectations, managers must always be consistent with the messages they convey if they want to claim an ethical purpose. Failure to do this implies an enormous risk, as it can negatively affect organizational outputs. Several studies have addressed this issue at different organizational levels. Some of the most representative examples are its causal relationship with variables like reputation, organizational identification, and employee engagement (Berrone, 2016).

The limitation of this study is its nature as a single case study that focuses on a single incident (although probably a relevant and valid one) that cannot be generalized as if it were the discovery of "revolutionary knowledge". However, one of the main aims of this study is the possibility of transferring this same framework into other contexts in order to probe and invigorate it. This practice can prepare the ground- 
work for further conclusions, which, in the long run, creates a solid contribution with both internal and external validity.

Finally, further studies can build upon the present contributions. Beyond the use of this same approach in further empirical studies, numerous possibilities could expand the knowledge through the use of this work in multiple avenues. On the one hand, legitimacy in general, and greenwashing in particular, are concepts with enormous potential for development in special contexts, like developing economies or sensitive industries. On the other hand, there are countless approaches to address issues like the ones presented in this work in many different ways (e.g., multi-case approaches, context comparisons, and causality studies), which for the sake of their better understanding deserve to be evaluated.

\section{REFERENCES}

1. Adams, C. A., \& Frost, G. R. (2006). Accessibility and functionality of the corporate web site: implications for sustainability reporting. Business Strategy and the Environment, 15(4), 275-287.

2. Ali, W., Frynas, J. G., \& Mahmood, Z. (2017). Determinants of Corporate Social Responsibility (CSR) Disclosure in Developed and Developing Countries: A Literature Review. Corporate Social Responsibility and Environmental Management.

3. Alonso-Almeida, M. M., Marimon, F., Casani, F., \& RodriguezPomeda, J. (2015). Diffusion of sustainability reporting in universities: Current situation and future perspectives. Journal of Cleaner Production, 106, 144-154.

4. ANLA (2013). Resolución 1309 del 2013: Por la cual se impone sanción ambiental y se toman otras determinaciones. República de Colombia. Ministerio de Ambiente y Desarrollo Sostenible. Autoridad Nacional de Licencias Ambientales. 201 p. December 18, 2013. Retrieved April 29 2016, from http://www.anla. gov.co/sites/default/files/11078_ res_1309_181213.pdf

5. ANLA (2014). Resolución 763 del 2014: Por la cual se resuelve un recurso de reposición y se toman otras determinaciones. República de Colombia. Ministerio de Ambiente y Desarrollo Sostenible. Autoridad Nacional de Licencias Ambientales. 93 p. July 14, 2014. Retrieved April 29, 2016, from http://www.anla. gov.co/sites/default/files/12923 res_0763_140714.pdf

6. Bansal, P., \& Clelland, I. (2004). Talking trash: Legitimacy, impression management, and unsystematic risk in the context of the natural environment. Academy of Management Journal, 47(1), 93-103.

7. Bachmann, P., \& Ingenhoff, D. (2016). Legitimacy through CSR disclosures? The advantage outweighs the disadvantages. Public Relations Review, 42(3), 386-394.

8. Berrone, P., Fosfuri, A., \& Gelabert, L. (2015). Does Greenwashing Pay Off? Understanding the Relationship Between Environmental Actions and Environmental Legitimacy. Journal of Business Ethics, 1-17.

9. Berrone, P. (2016). Green Lies: How Greenwashing can destroy a company (and how to go green without the wash). Createspace Independent Publishing Platform. $340 \mathrm{p}$.

10. Bowen, F., \& Aragon-Correa, J. A. (2014). Greenwashing in Corporate Environmentalism Research and Practice: The Importance of What We Say and Do. Organization \& Environment, 27(2), 107-112.

11. Bruno, K. (1992). The Greenpeace Book on Greenwash. Released at the Earth Summit in Rio de Janeiro. Amsterdam: Greenpeace International.

12. Campbell, D. J. (2000). Legitimacy theory or managerial reality construction? Corporate social disclosure in Marks and Spencer Plc corporate reports, 1969-1997. Accounting Forum, 24(1), 80-100. Blackwell Publishers Ltd.

13. Cho, C. H., \& Patten, D. M. (2007). The role of environmental disclosures as tools of legitimacy: A research note. Accounting, organizations and society, 32(7), 639-647.

14. Crilly, D., Hansen, M., \& Zollo, M. (2016). The grammar of decoupling: A cognitive-linguistic perspective on firms' sustainability claims and stakeholders' interpretation. Academy of Management Journal, 59(2), 705-729.

15. Deegan, C. (2014). An overview of legitimacy theory as applied within the social and environmental accounting literature. Sustainability accounting and accountability, 248-272.

16. De Villiers, C., \& van Staden, C. J. (2006). Can less environmental disclosure have a legitimising effect? Evidence from Africa. Accounting, Organizations and Society, 31(8), 763-781.

17. Delmas, M. A., \& Burbano, V. C. (2011). The drivers of greenwashing. California Management Review, 54(1), 64-87.

18. Dienes, D., Sassen, R., \& Fischer, J. (2016). What are the drivers of sustainability reporting? A systematic review. Sustainability Accounting, Management and Policy Journal, 7(2), 154-189. 
19. Dowling, J., \& Pfeffer, J. (1975). Organizational legitimacy: Social values and organizational behavior. Pacific sociological review, 18(1), 122-136.

20. Drummond Ltd. (2013, December). Hallazgos de la contingencia de la barcaza. Revista Drummond, 1, 4-6. Retrieved March 29, 2016, from http://www. emagcloud.com/semana/DRUMMOND_Ed_01/index.html\#/1/

21. Drummond Ltd. (2015). Informe de Sostenibilidad 2013-2014 (Rep.). Retrieved March 27, 2016, from http://www.drummondltd. com/noticias-publicaciones/ informes-de-sostenibilidad/

22. Drummondltd.com (2013, February 14). Declaración de Drummond LTD - Resultados de la investigación interna sobre el accidente de la barcaza [Press release]. Retrieved March 27, 2016, from http://www.drummondltd. com/declaracion-de-drummondltd-accidente-resultados-investigacion-interna/

23. Drummondltd.com (2014, January 19). Drummond Ltd. responde con hechos y pregunta ¿por qué? [Press release]. Retrieved March 29, 2016, from http://www.drummondltd.com/ drummond-ltd-responde-conhechos-y-pregunta-por-que/

24. Elpais.com.co (2013, February 21). "No sabemos cuántas toneladas de carbón cayeron al mar": Drummond. El PaHs. Retrieved April 2, 2016, from http://www.elpais.com.co/elpais/economia/noticias/sabemos-cuantas-toneladascarbon-cayeron-mar-drummond.

25. Eltiempo.com (2013, February 17). "Cayeron al mar 300 toneladas de carbón”, dice la Drummond. EL TIEMPO. Retrieved March 30 2016, from http://www.eltiempo. com/archivo/documento/CMS12600377

26. Eisenhardt, K. M. (1989). Building theories from case study research. Academy of management review, 14(4), 532-550.

27. Festinger, L. (1962). A theory of cognitive dissonance, 2. Stanford University Press.
28. Forbes.com (2017). America's Largest Private Companies. Retrieved from https://www.forbes. com/companies/drummond/ (accessed on 13 Mar, 2017).

29. Frost, G., Jones, S., Loftus, J., \& Van Der Laan, S. (2005), A Survey of Sustainability Reporting Practices of Australian Reporting Entities. Australian Accounting Review, 15, 89-96.

30. Garay, L. J., Rudas, G., Espitia, J. E., Mena, J. A., Pardo, L. A., Fierro, J., Olivero, J., Caballero, K., Guerrero, A., Vargas, F., \& Negrete, R. E. (2013). Minerнa en Colombia: Institucionalidad y territorio, paradojas y conflictos. Bogotá: Contraloría General de la República.

31. Gray, R., Owen, D., \& Adams, C. (1996). Accounting \& accountability: changes and challenges in corporate social and environmental reporting. Prentice Hall.

32. Guthrie, J., \& Parker, L. D. (1989). Corporate social reporting: a rebuttal of legitimacy theory. Accounting and business research, 19(76), 343-352.

33. Huertas, J. I., Huertas, M. E., Izquierdo, S., \& González, E. D. (2012). Air quality impact assessment of multiple open pit coal mines in northern Colombia. Journal of environmental management, 93(1), 121-129.

34. Invemar (2013). Concepto técnico sobre el efecto del derrame de carbón sobre el ecosistema marino, producido por la maniobra de rescate de la barcaza TS-115 de propiedad de la Compañía American Port Company INC. (Tech. No. CPT-BEM-005-13) for Ministerio de Ambiente y Desarrollo Sostenible y la ANLA. Retrieved February 01, 2016, from Drummond Ltd. website: http:// www.drummondltd.com/wp-content/uploads/4.-Concepto-CPTBEM-005-13-Informe-INVEMAR. pdf

35. Jiménez, G. (2014).

Multinacionales y responsabilidad social empresarial en la construcciyn de paz en Colombia. Cuadernos de administración, 27(48), 67-96.
36. Katamba, D., \& Nkiko, C. M. (2017). The CSR Communications and Reporting Landscape in Developing Countries. In Handbook of Integrated CSR Communication (pp. 343-358). Springer International Publishing.

37. Layton, J. C. (2013, February 22). Mineros prometen reducir la pobreza extrema en Colombia - See more at: Http:// www.lapatria.com/economia/ mineros-prometen-reducir-lapobreza-extrema-en-colombia26902\#sthash.Xw5P26Yi.dpuf. La Patria. Retrieved May 4, 2016, from http://www.lapatria.com/ economia/mineros-prometenreducir-la-pobreza-extrema-encolombia-26902

38. Linares, J. M. (2013, February 21). Rescue Operation of the Barge TS115. In 2nd. Conference of the High Scale Mining Industry (SMGE). Retrieved April 01, 2016 from http://www.drummondltd. com/wp-content/uploads/2. Drummond-LTD_-Presentacioncongreso-SMGE-Febrero2013.pdf

39. Mahoney, L. S., Thorne, L., Cecil, L., \& LaGore, W. (2013). A research note on standalone corporate social responsibility reports: Signaling or greenwashing? Critical Perspectives on Accounting, 24(4), 350-359.

40. Marquis, C., \& Toffel, M. W. (2011). The Globalization of Corporate Environmental Disclosure: Accountability or Greenwashing? Harvard Business School.

41. Milne, M. J., \& Patten, D. M. (2002). Securing organizational legitimacy: An experimental decision case examining the impact of environmental disclosures. Accounting, Auditing \& Accountability Journal, 15(3), 372-405.

42. Molinski, D. (2013, December 19). Colombia Fines Drummond for Dumping Coal. The Wall Street Journal. Retrieved from https:// www.wsj.com/articles/SB1000142 40527023037737045792684320789 35884 (accessed on 13 Mar, 2017). 
43. Morhardt, J. E., Baird, S., \& Freeman, K. (2002). Scoring corporate environmental and sustainability reports using GRI 2000, ISO 14031 and other criteria. Corporate Social Responsibility and Environmental Management, 9(4), 215-233.

44. Otálora, R. (2015). El Poder Negociador de la Empresa Transnacional en la Expedición de la Legislación Minera en Colombia. Revista Republicana, 18, 181-210.

45. Plazas, F. A. (2016). Análisis de la evolución de la inversión extranjera directa en el sector minero del carbón en Colombia de 2004 a $2013^{*}$ /Analysis of the evolution of foreign direct investment in the coal mining sector in Colombia from 2002 to 2013. Apuntes del CENES, 35(61), 51.

46. Sarmiento, N. (2008). ¿Bondad o estrategia? tejiendo responsabilidad social en el mundo del carbón. Colombia Internacional, 67, 132-151.

47. Shaefer, S. (2014, February 7) Drummond and Colombia Both Suffer in Clash. The Wall Street Journal. Retrieved April 12, 2016, from http://www.wsj.com/articles/ SB10001424052702304851104579 363322390004550

48. Simco.gov.co (n.d.). Sistema de Informaciyn Minero Colombiano. Retrieved from http://simco.gov. co (accessed on 9 April, 2017).

49. Snider, J., Hill, R. P., \& Martin, D. (2003). Corporate social responsibility in the 21 st century: A view from the world's most successful firms. Journal of Business ethics, 48(2), 175-187.

50. Spence, C. (2009). Social and environmental reporting and the corporate ego. Business Strategy and the Environment, 18(4), 254265.
51. Valencia, J. A. (Ed.) (2014) Indicadores De La Minería En Colombia (Colombia, Ministerio de Minas y Energía, Unidad de Planeación Minero- Energética). Retrieved April 22, 2016, from http://www.upme.gov.co/Docs/ Plan_Minero/2014/Indicadores de la Minería en Colombia.pdf

52. Walker, K., \& Wan, F. (2012) The Harm of Symbolic Actions and Green-Washing : Corporate Actions and Communications on Environmental Performance and Their Financial Implications. Journal of business ethics, 109(2), 227-242

53. Yekini, K. C., Burrows, L., \& Omoteso, K. (2014). A Semiotic approach to evaluating the quality and veracity of CSR reporting. Accounting and Finance.

54. Yin, R. (1994). Case study research: Design and methods. Beverly Hills. 